\title{
Analisis Nilai Kapasitansi Komposit Lithium Besi Oksida (Li5FeO4) dan Karbon Aktif Kulit Biji Mete sebagai Bahan Dasar Elektroda Baterai Lithium: Efek Variasi Massa
}

\author{
Ahmad $^{1)} *$, Erniwati ${ }^{2)}$, Vivi Hastuti Rufa Mongkito ${ }^{2)}$ \\ 1)* Alumni Jurusan Pendidikan Fisika, Fakultas Keguruan dan Ilmu Pendidikan ,Universitas Halu Oleo \\ ${ }^{2)}$ Dosen Jurusan Pendidikan Fisika, Fakultas Keguruan dan Ilmu Pendidikan ,Universitas Halu Oleo \\ *Email: ahmadphysic016@gmail.com
}

\begin{abstract}
Abstrak: Penelitian tentang pembuatan bahan elektroda baterai lithium dari komposit $\mathrm{Li}_{5} \mathrm{FeO}_{4}$ dengan karbon aktif kulit biji mete telah dilakukan oleh peneliti-peneliti sebelumnya. Tetapi, dalam penelitian tersebut tidak ditinjau efek dari penambahan karbon aktif pada bahan elektroda baterai lithium. Tujuan penelitian ini adalah untuk mengetahui pengaruh perbandingan komposisi massa $\mathrm{Li}_{5} \mathrm{FeO}_{4}$ dan karbon aktif kulit biji mete terhadap nilai kapasitansi bahan dasar elektroda baterai lithium. Bahan dasar elektroda ini dikembangkan dengan menggunakan metode solid state suhu tinggi. Bahan yang digunakan adalah besi oksida $\mathrm{Fe}_{2} \mathrm{O}_{3}$ dari pasir besi dan $\mathrm{LiOH} \cdot \mathrm{H}_{2} \mathrm{O}$ yang dihomogenkan dengan temperature sintering $850^{\circ} \mathrm{C}$ selama 15 jam dengan perbandingan kimposisi $6 / 1$ untuk menghasilkan $\mathrm{Li}_{5} \mathrm{FeO}_{4}$. Kemudian $\mathrm{Li}_{5} \mathrm{FeO}_{4}$ dikompositkan dengan karbon aktif kulit biji mete dengan fraksi massa karbon aktif sebesar $20 \%, 40 \%, 50 \%$ dan $60 \%$. Selanjutnya dikarakterisasi menggunakan cyclic voltammetry. Hasil karakterisasi cyclic voltammetry untuk fraksi massa 60\% menghasilkan kapasitansi sebesar 4,7 F/g, fraksi massa 50\% menghasilkan kapasitansi sebesar 59,1 F/g, fraksi massa 40\% menghasilkan kapasitansi sebesar 87,3 F/g, dan fraksi massa $20 \%$ menghasilkan kapasitansi sebesar $243 \mathrm{~F} / \mathrm{g}$. Dari keempat variasi fraksi massa, kapasitansi yang memenuhi kapasitansi elektroda baterai lithium di pasaran adalah fraksi massa karbon aktif $20 \%$.
\end{abstract}

Kata Kunci: $\mathrm{Li}_{5} \mathrm{FeO}_{4}$, Karbon Aktif Kulit Biji Mete, Metode Solid State Suhu Tinggi, Siklik Voltametri

Abstract: Previous researchers have investigated the manufacture of lithium battery electrode materials from $\mathrm{Li} 5 \mathrm{FeO} 4$ composites with activated carbon of cashew nutshells. However, the effect of combining activated carbon to the lithium battery electrode material was not reviewed. The purpose of this study was to determine the effect of the comparison of the mass composition of $\mathrm{LiSFeO4}$ and cashew nut shell active carbon on the capacitance value of the lithium battery electrode. These electrodes generated using the high-temperature solid-state method. The material used is iron oxide $\mathrm{Fe} 2 \mathrm{O} 3$ from iron sand and $\mathrm{LiOH}$.H2O, which homogenized with a sintering temperature of $850^{\circ} \mathrm{C}$ for 15 hours with a ratio of 6/1 to produce Li5FeO4. Then Li5FeO4 was compiled with activated carbon of cashew nut shells with a mass fraction of activated carbon $60 \%, 50 \%, 40 \%$, and $20 \%$. Furthermore, it characterized using cyclic voltammetry. The results of cyclic voltammetry characterization for a mass fraction of $60 \%$ produce a capacitance of $4.7 \mathrm{~F} / \mathrm{g}$, a mass fraction of $50 \%$ produces a capacitance of $59.1 \mathrm{~F} / \mathrm{g}$, a mass fraction of $40 \%$ produces a capacitance of $87,3 \mathrm{~F} / \mathrm{g}$, and a mass fraction of $20 \%$ produces capacitance of $243 \mathrm{~F} / \mathrm{g}$. From the four variations of mass fraction, the capacitance that meets the lithium battery electrode capacitance on the market is the mass fraction of $20 \%$.

Keyword: $\mathrm{Li}_{5} \mathrm{FeO}_{4}, \mathrm{Fe}_{2} \mathrm{O}_{3}$, Activated Carbon Cashew Nut Shells, High Temperature Solid State Method, Cyclic Voltammetry

\section{PENDAHULUAN}

Baterai lithium merupakan salah satu jenis baterai yang terus dikembangkan hingga saat ini. Sejak pertama kali diluncurkan oleh Sonny pada tahun 1991, baterai lithium menjadi sumber energi listrik yang paling banyak digunakan (Rao, 2013). Penggunaannya tidak hanya pada peralatan elektronik skala kecil seperti jam, handphone dan laptop tetapi juga pada peralatan listrik skala besar seperti kendaraan listrik. Hal ini karena kelebihan yang dimiliki baterai lithium-ion dibandingkan dengan baterai jenis lainnya. Kelebihan yang dimilikinya adalah beda potensial tinggi, densitas energi yang tinggi, kapasitas spesifik yang tinggi dan lifecycle yang panjang (500-1000 siklus), (Allison, 2015; Ahmad et al. 2019). Komponen utama baterai lithium yaitu elektroda telah banyak dikembangkan melalui proses sintesis seperti lithium mangan oxide (LiMn2O4) lithium cobalt oxide ( $\mathrm{LiCoO} 2)$ dan lithium iron phospate (LFP) (Hamid, 2012). Selain itu, dikembangkan lagi elektroda baterai $\mathrm{Li}$-Ion jenis $\mathrm{Li} 5 \mathrm{FeO} 4$ dari material besi oksida $(\mathrm{Fe} 2 \mathrm{O} 3)$ menjadi elektroda untuk baterai lithium sekunder (rechargeable). Jika dibandingkan dengan elektroda baterai Li-Ion dari material utama $\mathrm{Co}, \mathrm{Ni}, \mathrm{Mn}$ dan $\mathrm{P}, \mathrm{Li} 5 \mathrm{FeO} 4$ memiliki keunggulan karena ketersediaannya yang melimpah, murah, ramah lingkungan dan memiliki 
stabilitas termal yang lebih besar. Serbuk besi oksida lithium (Li5FeO4) bisa dihasilkan dari sintesis $\mathrm{LiOH}, \mathrm{H} 2 \mathrm{O}$ dan $\mathrm{Fe} 2 \mathrm{O} 3$ menggunakan metode solid state suhu tinggi. Bahan-bahan ini mudah didapatkan dan bisa disintesis dari bahan alam. Elektroda jenis $\mathrm{Li5FeO} 4$ memiliki kapasitansi yang sangat besar. Berdasarkan penelitian sebelumnnya telah diperoleh elektroda $\mathrm{Li} 5 \mathrm{FeO} 4$ dengan penambahan karbon aktif sebanyak 10\% menghasilkan kapasitansi spesifik sebesar $200 \mathrm{~F} / \mathrm{g}$, tegangan yang besar yaitu sekitar 1,5 Volt (Rahardjo, 2015). Penambahan karbon aktif pada elektroda baterai lithium bertujuan untuk meningkatkan konduktivitas listrik baterai lithium. Karbon aktif juga dapat ditambahkan pada elektroda baterai lithium yang terbuat dari bahan selain grafit. Seperti lithium titanat (Li4Ti5O12) yang memiliki konduktivitas rendah dapat ditingkatkan dengan penambahan karbon sintesis jenis MWCNT, (Subhan, 2015). Namun, penggunaan karbon sintesis memiliki harga yang mahal dan tidak ramah lingkungan (Adrianto et al. 2019). Sebagai alternatifnya karbon sintesis dapat diganti dengan karbon alami yang berasal dari biomassa. Salah satu sumber karbon yang dapat dijadikan sebagai karbon aktif pengganti karbon sintesis adalah kulit biji mete. Berdasarkan hasil penelitian yang dilakukan oleh Anas (2015) kandungan karbon dari kulit biji mete sebanyak 95,56\%. Karbon aktif kulit biji mete dapat menjadi alternatif pengganti karbon sintesis untuk meningkatkan konduktivitas listrik pada elektroda baterai litium. Sebagaiman yang dilakukan Amin (2019) telah berhasil membuat bahan elektroda baterai jenis $\mathrm{Li5FeO} 4$ dari ekstrak pasir besi dan karbon aktif kulit biji mete menghasilkan nilai kapasitansi sebesar 58 F/g. Akan tetapi, dalam penelitian sebelumnya belum diteliti pengaruh komposisi massa karbon aktif terhadap nilai kapasitansi spesifik baterai litium.

\section{METODE}

Penelitian ini dilaksanakan pada bulan Februari 2019 sampai selesai bertempat di laboratorium Jurusan Pendidikan Kimia. Prosedur Penelitian

a. Bagan Alir Prosedur Penelitian

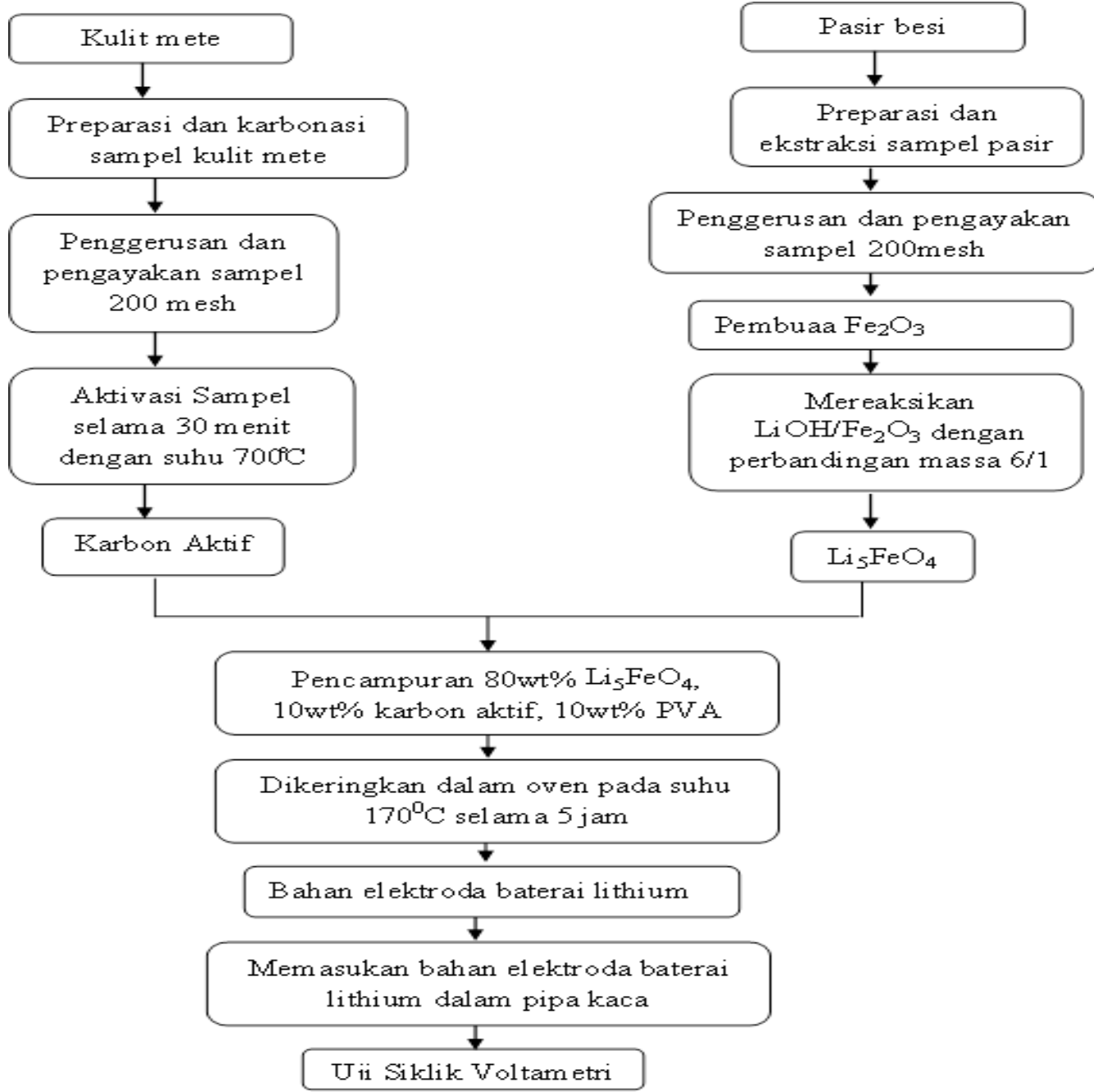

Gambar 1. Bagan Alir Pembuatan Bahan Elektroda Baterai Li-Ion $\mathrm{Li}_{5} \mathrm{FeO}_{4}$ 
b. Pembuatan Arang Aktif

Kulit biji mete dicuci menggunakan aquades lalu dijemur dibawah sinar matahari hingga kering. Lalu dikarbonasi menggunakan tabung porolisis dengan suhu $450^{\circ} \mathrm{C}$ selama 9 jam. Selanjutnya digerus menggunakan mortar dan diayak menggunakan ayakan 200mesh. Tahap selanjutnya dilakukan aktivasi menggunakan tanur dengan suhu $700^{\circ} \mathrm{C}$ selama 30 menit untuk membuka permukaan pori dari arang kulit biji mete dan memisahkannya dari pengotor-pengotornya.

c. Sintesis $\mathrm{Fe}_{2} \mathrm{O}_{3}$ dari Pasir Besi

Merujuk pada penelitian Rajab (2013), proses sintesis $\mathrm{Fe} 2 \mathrm{O} 3$ dari pasir besi dilakukan melalui langkah-langkah sebagai berikut:

1) Timbang serbuk pasir besi sebanyak 30 gram kemudian dimasukkan ke dalam gelas kimia dan dicampur dengan $100 \mathrm{~mL} \mathrm{HCl} \mathrm{(37 \% ).}$

2) Lakukan stirer selama 60 menit dengan suhu [ 70) ^0 C yang dijaga konstan.

3) Saring larutan hasil stirer menggunakan kertas saring untuk diambil filtratnya, sedangkan residu hasil saringan dibuang.

4) Masukan larutan $\mathrm{NH} 4 \mathrm{OH} 6$ Molaritas sebanyak 50 $\mathrm{mL}$ ke dalam gelas kimia kemudian ditambahkan filtrat pasir besi dari larutan $\mathrm{HCl}$ sambil diaduk menggunakan pengaduk magnetik dengan suhu konstan $70^{\wedge} 0 \mathrm{C}$.

5) Saring larutan dari hasil pengadukan tersebut lalu diambil residunya.

6) Cuci residu hasil saringan dengan aquades hingga bersih.

7) Panaskan dalam oven dengan suhu $105^{\circ} \mathrm{C}$ hingga kering, maka diperolehlah serbuk $\mathrm{Fe} 2 \mathrm{O} 3$.

d. Pembuatan $\mathrm{Li}_{5} \mathrm{FeO}_{4}$

Merujuk pada penelitian Rahadjo (2015) dan Amin
(2019), untuk membuat sintesis $\mathrm{Li}_{5} \mathrm{FeO}_{4}$ yang dilakukan adalah

1) Memperhitungkan massa masing-masing bahan LiOH : $\mathrm{Fe}_{2} \mathrm{O}_{3}$ dengan perbandingan 6:1. Untuk memperoleh perbandingan yang tepat maka dibutuhkan stoikiometri yang benar seperti berikut:

$$
\text { 10LiOH. } \mathrm{H}_{2} \mathrm{O}+\mathrm{Fe}_{2} \mathrm{O}_{3} \rightarrow 2 \mathrm{Li}_{5} \mathrm{FeO}_{4}+
$$

$6 \mathrm{H}_{2} \mathrm{O}$

2) Selanjutnya, melarutkan $\mathrm{LiOH}$ dalam bentuk serbuk kedalam $\mathrm{H}_{2} \mathrm{O}$ (aquades). Setelah proses pelarutan, serbuk $\mathrm{LiOH}$ terikat dengan air sehingga menjadi LiOH. $\mathrm{H}_{2} \mathrm{O}$. Lalu, mencampurkan $\mathrm{Fe}_{2} \mathrm{O}_{3}$ kedalam larutan $\mathrm{LiOH} . \mathrm{H}_{2} \mathrm{O}$ sesuai massa hasil perbandingan.

3) Sampel kemudian dipanaskan menggunakan tanur pada suhu $850^{\circ} \mathrm{C}$

e. Pembuatan Bahan Elektroda $\mathrm{Li}_{5} \mathrm{FeO}_{4} / \mathrm{C}$

Metode pembuatan katoda baterai Li-Ion Li5FeO4 ini merujuk pada penelitian Rahadjo (2015) sebagai berikut:

1) Hitung persen berat (wt\%) pada setiap bahan yang dibutuhkan seperti Li5FeO4, Polyvinyl Alcohol (PVA) dan karbon aktif kulit biji mete.

2) Campur $\mathrm{Li} 5 \mathrm{FeO} 4$ dan karbon aktif kulit biji mete, dimana fraksi massa karbon aktif yang digunakan sebesar $60 \%, 50 \%, 40 \%$, dan $20 \%$.

3) Tambahkan PVA untuk merekatkan campuran antara $\mathrm{Li} 5 \mathrm{FeO} 4$ dan karbon aktif sebanyak $10 \%$ dari massa total.

4) Panaskan campuran tersebut pada suhu $170^{\circ} \mathrm{C}$ selama 5 jam.

5) Masukan sampel yang telah kering ke dalam silinder kaca berukuran berdiameter $2 \mathrm{~mm}$ dan panjang $8 \mathrm{~cm}$ yang telah dipasang bersama kawat tembaga seperti pada gambar berikut.

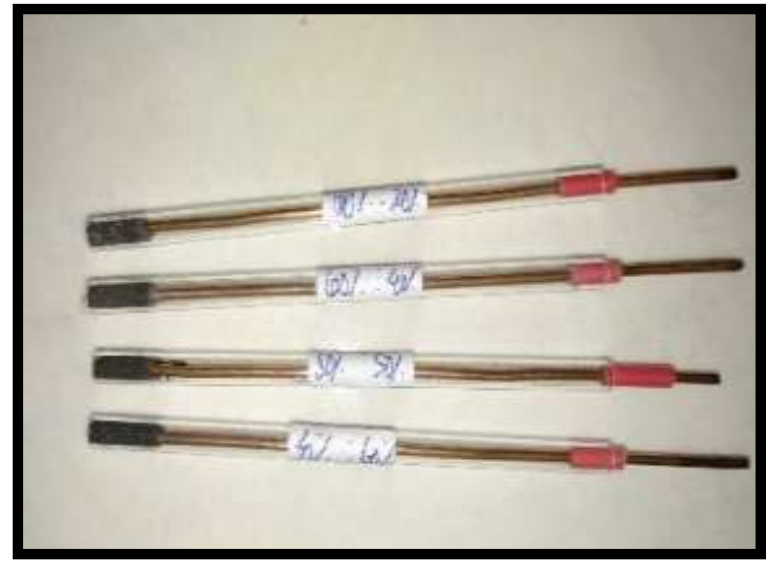

Gambar 2. Pengisian Sampel dalam Tabung Kaca

f. Teknik Analisis Data

Teknik analisis data dalam penelitian ini adalah Karakterisasi elektrokimia menggunakan cyclic voltammetry dan metode four point probe. Alat ciclyc voltametri dapat ditunjukan pada gambar berikut. 


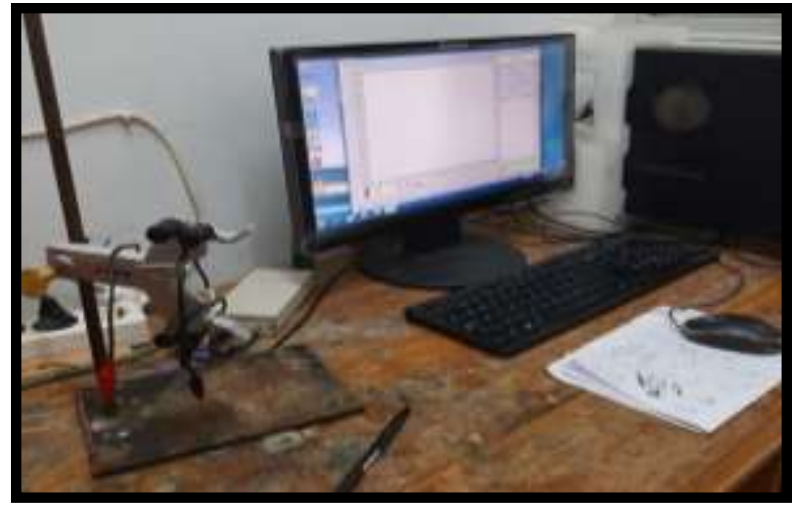

Gambar 3. Ciclyc Voltammetry

Pengujian Ciclyc Voltammetry ini yang bertujuan untuk melihat adanya reaksi oksidasi dan reduksi yang terbentuk pada sampel dan menentukan besar nilai kapasitansi listrik.
Data yang diperoleh berupa grafik voltammogram, yaitu kurva potensial (V) terhadap arus (A). Nilai kapasitansi listrik katoda dapat diperoleh dengan persamaan:

$$
C_{s p}=\frac{I_{\text {masuk }}-I_{\text {keluar }}}{s m}
$$

Ket:

$\mathrm{C}_{\mathrm{sp}}=$ Kapasitansi spesifik $(\mathrm{F})$

$\mathrm{I}=\operatorname{Arus} \operatorname{listrik}(\mathrm{A})$

$\mathrm{s}=$ laju scan rate $(\mathrm{mV} / \mathrm{s})$

$\mathrm{m}=$ massa katoda $($ gram $)$

\section{HASIL PENELITIAN}

Hasil penelitian analisis nilai kapasitansi komposit $\mathrm{Li}_{5} \mathrm{FeO}_{4}$ dan karbon aktif kulit biji mete ditampilkan dalam bentuk gambar kurva voltamogram dan tabel kapasitansi spesifik seperti yang ditunjukan pada Gambar 4 sampai Gambar 9 dan Tabel 1.
1. Voltamogram Kapasitansi Komposit $\mathrm{Li}_{5} \mathrm{FeO}_{4}$ dan Karbon Aktif Kulit Biji Mete

a. Voltamogram Elektroda Baterai Lithium dengan Fraksi Massa Karbon Aktif 60\%

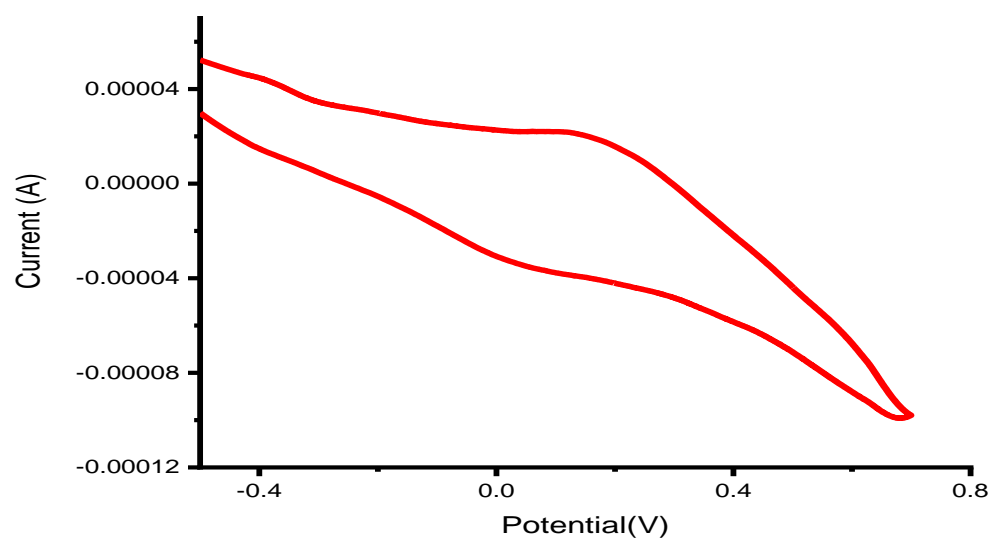

Gambar 4. Voltamogram Elektroda Baterai Lithium dengan fraksi massa Karbon Aktif 60\%. 
b. Voltamogram Elektroda Baterai Lithium dengan Fraksi Massa Karbon Aktif 50\%

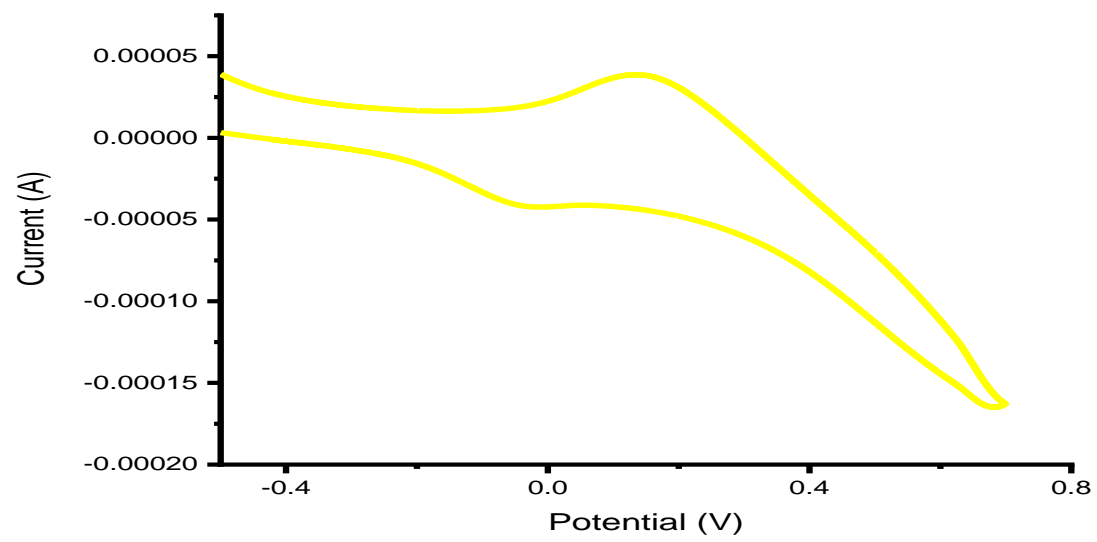

Gambar 5. Voltamogram Elektroda Baterai Lithium dengan fraksi massa Karbon Aktif 50\%

c. Voltamogram Elektroda Baterai Lithium dengan $\quad$ Fraksi Massa Karbon Aktif $40 \%$

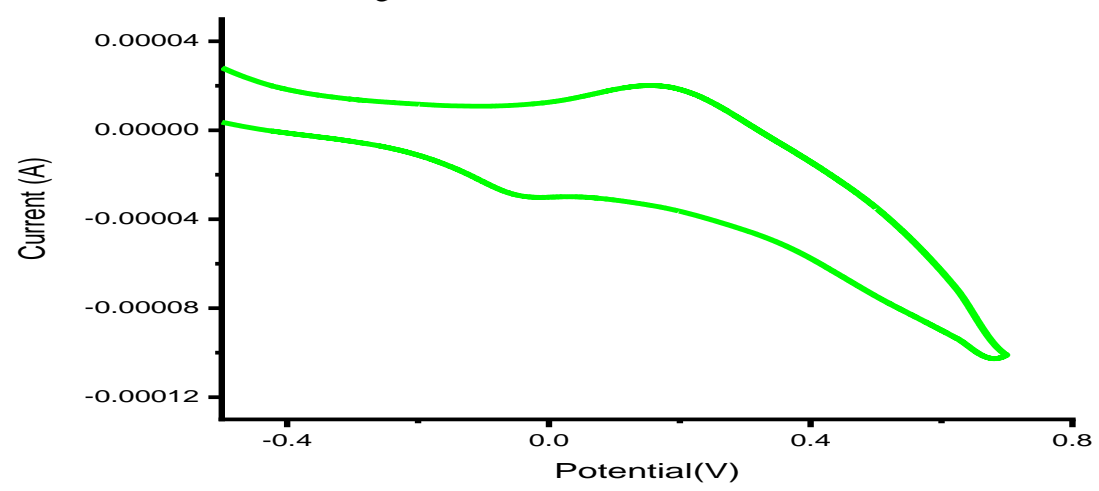

Gambar 6. Voltamogram Elektroda Baterai Lithium dengan fraksi massa Karbon Aktif 40\%

d. Voltamogram Elektroda Baterai Lithium dengan

Fraksi Massa Karbon Aktif 20\%

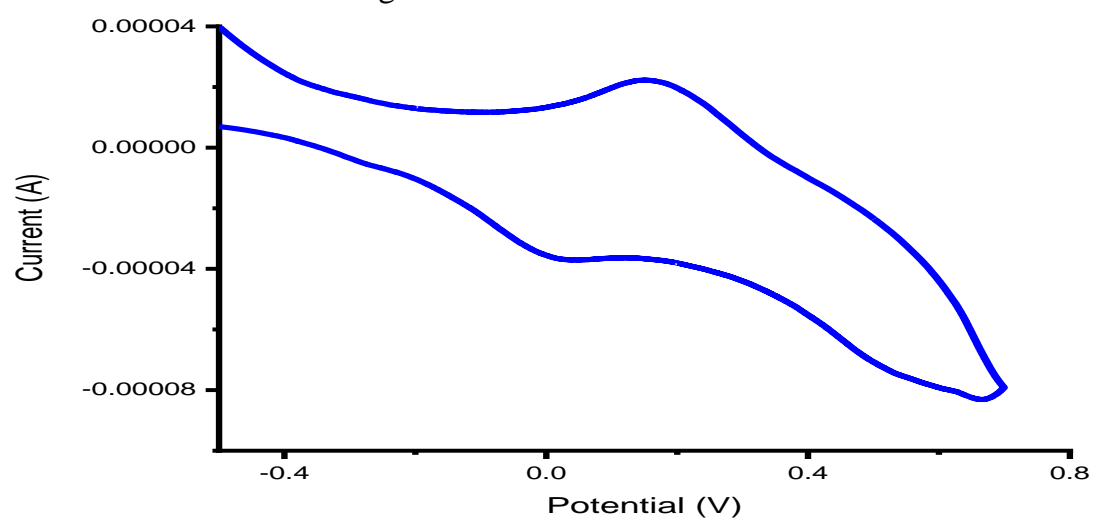

Gambar 7. Voltamogram Elektroda Baterai Lithium dengan fraksi massa Karbon Aktif 20\% 


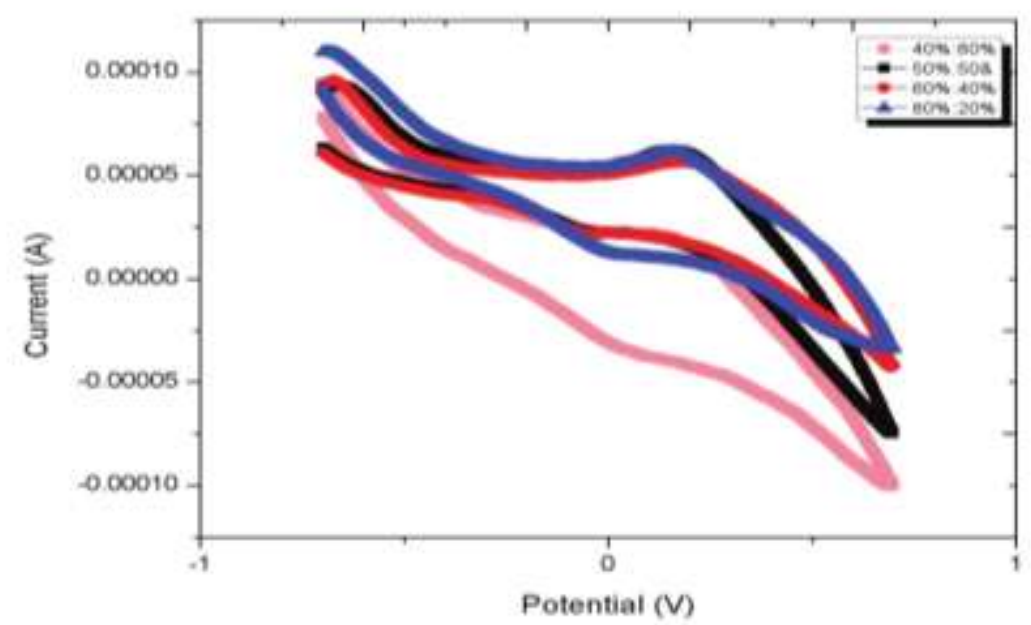

Gambar 8. Voltamogram Elektroda Baterai Lithium dengan fraksi massa Karbon Aktif 60\%, 50\%, 40\%, dan 20\%

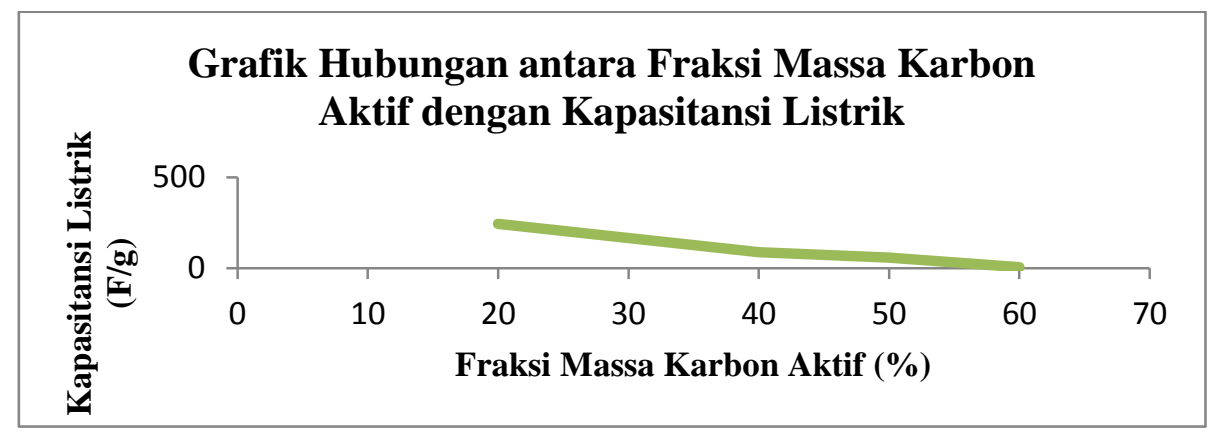

Gambar 9. Hubungan antara Fraksi Massa Karbon Aktif Kulit Biji Mete dengan Kapasitansi Listrik

3. Kapasitansi Spesifik Komposit $\mathrm{Li}_{5} \mathrm{FeO}_{4}$ dan Karbon Aktif Kulit Biji Mete

\begin{tabular}{cccccc}
\hline $\begin{array}{c}\text { Fraksi Massa } \\
\text { Karbon Aktif }\end{array}$ & $\begin{array}{c}\text { Potensial Peak } \\
\text { Anodik/Epa } \\
(\mathbf{V})\end{array}$ & $\begin{array}{c}\text { Potensial Peak } \\
\text { Cathodik/Epc } \\
(\mathbf{V})\end{array}$ & $\begin{array}{c}\text { Arus Peak } \\
\text { Anodik/Ipa } \\
(\mathbf{A})\end{array}$ & $\begin{array}{c}\text { Arus Peak } \\
\text { Cathodik/Ipc (A) }\end{array}$ & C (F/g) \\
\hline $60 \%$ & $5,6 \times 10^{-2}$ & $1 \times 10^{-1}$ & $2,13 \times 10^{-6}$ & $2,84 \times 10^{-6}$ & 4,7 \\
\hline $50 \%$ & $-1,1 \times 10^{-1}$ & $1,32 \times 10^{-1}$ & $-2,65 \times 10^{-5}$ & $-1,77 \times 10^{-5}$ & 59,1 \\
\hline $40 \%$ & $7 \times 10^{-3}$ & $1,47 \times 10^{-1}$ & $-2,24 \times 10^{-5}$ & $-9,25 \times 10^{-6}$ & 87,3 \\
\hline $20 \%$ & $4 \times 10^{-2}$ & $1,58 \times 10^{-1}$ & $-3,3 \times 10^{-5}$ & $3,31 \times 10^{-6}$ & 243 \\
\hline
\end{tabular}

\section{PEMBAHASAN}

Kurva voltamogram pada Gambar 4.1 menunjukan kurva $\mathrm{Li}_{5} \mathrm{FeO}_{4} / \mathrm{C}$ dengan fraksi massa karbon aktif kulit biji mete $60 \%$. Kurva voltamogram yang dihasilkan dengan fraksi massa $60 \%$ memiliki lebar kurva arus charge (Ic) dan arus discharge (Id) yang kecil. Kurva arus charge (Ic) ditunjukan oleh kurva melengkung terbuka ke bawah. Kurva ini disebut juga kurva arus anodik karena arus yang terukur selama pengisian adalah arus anodik, (Chen dkk, 2019). Sedangkan kurva arus discharge (Id) ditunjukan oleh kurva yang melengkung terbuka keatas. Kurva ini disebut
Tabel 4.1. Nilai Hasil Voltamogram Elektroda Baterai Lithium $\mathrm{Li}_{5} \mathrm{FeO}_{4} / \mathrm{C}$ dengan Fraksi Massa Karbon Aktif Kulit Bii Mete 60\%, 50\%, 40\% dan $20 \%$

juga sebagai kurva arus katodik karena arus yang terukur selama proses pengosongan adalah arus katodik, (Chen dkk, 2019). Kurva arus charge (Ic) dan arus discharge (Id) memiliki bentuk yang tidak simetris. Hal ini menunjukan bahwa reaksi yang terjadi bersifat irreversibel (Hanfeng dkk, 2014). Bentuk kurva arus charge (Ic) dan arus discharge (Id) yang tidak dapat kembali ke posisi semula semakin memperkuat bahwa rekasi yang terjadi bersifat irreversible (Rahardjo \& Supardi, 2015). Reaksi yang terjadi bersifat irreversible dipengaruhi oleh kinetika transfer elektron yang berlangsung lambat (Syafindra dkk, 
2017) akibat terbentuknya porositas pada bahan elektroda baterai lithium (Alim dkk, 2017). Munculnya porositas disebabkan sampel yang dibuat masih dalam bentuk serbuk dan tidak dipadatkan. Sehingga, bahan dasar elektroda baterai lithium yang dihasilkan hanya dapat dijadikan sebagai baterai lithium primer.

Selanjutnya kurva voltamogram pada Gambar 4.2 merupakan kurva voltamogram dengan komposisi massa yang sama antara Li5FeO4 dan karbon aktif kulit biji mete dimana fraksi massa kulit biji mete 50\%. Lebar kurva arus charge (Ic) dan arus discharge (Id) yang dihasilkan lebih besar dari kurva voltamogram pada fraksi massa $60 \%$. Lebar kurva voltamogram menunjukan besar kecilnya nilai kapasitansi yang dihasilkan. Voltamogram dengan kurva arus charge (Ic) dan arus discharge (Id) yang paling luas mengindikasikan nilai kapasitansi spesifik yang besar (Taer dkk, 2015). Berdasarkan grafik voltamogram menunjukan bahwa fraksi massa karbon aktif kulit biji mete 50\% memiliki nilai kapasitansi yang lebih besar dibandingkan dengan fraksi massa $60 \%$.

Bertambahnya lebar kurva voltamogram dipengaruhi oleh komposisi Li5FeO4. Dapat dilihat kurva voltamogram pada Gambar 4.3 yang merupakan gambar kurva voltamogram hasil siklik voltametri dengan komposisi massa $\mathrm{Li} 5 \mathrm{FeO} 4$ lebih banyak dari karbon aktif dimana fraksi massa karbon aktif kulit biji mete $40 \%$ memiliki lebar kurva voltamogram lebih besar daripada kurva dengan fraksi massa $50 \%$ maupun fraksi massa $60 \%$. Begitu juga dengan kurva voltamogram pada Gambar 4.4 yang merupakan kurva voltamogram hasil siklik voltametri dengan komposisi massa $\mathrm{Li5FeO} 4$ terbanyak yaitu sebanyak $80 \%$. Sehingga dari keempat kurva voltamogram, kurva dengan fraksi massa karbon aktif kulit biji mete $20 \%$ termasuk voltamogram dengan lebar kurva arus charge (Ic) dan arus discharge (Id $\neg)$ yang lebih besar diantara semua fraksi massa. Jumlah komposisi massa $\mathrm{Li5FeO} 4$ mempengaruhi besar kecilnya lebar kurva voltamogram. Semakin banyak komposisi massa $\mathrm{Li5FeO} 4$ maka lebar kurva yang dihasilkan juga akan semakin besar. Keempat kurva voltamogram tersebut memiliki bentuk yang hampir sama yang dapat dilihat pada Gambar 4.5 yang menampilkan kurva voltamogram untuk semua fraksi massa. Menurut Nursiti (2018), tipe grafik yang sama menunjukan bahwa perlakuan yang diberikan tidak mempengaruhi kestabilan elektroda.

Hubungan antara fraksi massa komposit Li5FeO4 dan karbon aktif kulit biji mete ditunjukan oleh grafik pada Gambar 4.6. Pada Gambar 4.6 menampilkan hubungan karbon aktif kulit biji mete dengan kapasitansi listrik bahan elektroda baterai lithium. Kurvanya turun seiring bertambahnya komposisi karbon aktif kulit biji mete. Kondisi terbalik semakin bertambah jumlah $\mathrm{Li} 5 \mathrm{FeO} 4$ atau berkurangnya komposisi karbon aktif kulit biji mete maka nilai kapasitansi spesifik elektroda baterai lithium semakin bertambah. Sehingga, penambahan karbon aktif tidak menambah nilai kapasitansi listrik elektroda baterai lithium yang dihasilkan.
Berdasarkan Tabel 6, nilai kapasitansi bahan elektroda baterai lithium yang paling kecil terdapat pada fraksi massa karbon aktif kulit biji mete $60 \%$ yaitu sebesar $4,7 \mathrm{~F} / \mathrm{g}$, untuk fraksi massa 50\% memiliki kapasitansi sebesar 59,1 $\mathrm{F} / \mathrm{g}$, untuk fraksi massa $40 \%$ memiliki kapasitansi sebesar $87,3 \mathrm{~F} / \mathrm{g}$, dan untuk fraksi massa $20 \%$ memiliki kapasitansi sebesar 243 F/g. Nilai kapasitansi bahan elektroda baterai lithium bertambah besar seiring bertambahnya komposisi massa Li5FeO4. Jika dibandingkan dengan kapasitansi baterai lithium jenis handphone Advan S5E 4G yang memiliki kapasitansi sebesar $2200 \mathrm{mAh}$, tegangan 3,8 volt, dan bermassa 10 gram atau setara dengan 208,4 F/g, maka fraksi massa karbon aktif kulit biji mete $20 \%$ telah setara dengan kapasitansi baterai lithium yang dijual dipasaran.

\section{KESIMPULAN DAN SARA}

Hasil karakteristik siklik voltametri menunjukan bahwa variasi massa komposit $\mathrm{Li5FeO} 4$ dan karbon aktif mempengaruhi nilai kapasitansi elektroda baterai lithium yang dihasilkan. Nilai kapasitansi bahan elektroda baterai lithium semakin bertambah besar seiring bertambahnya komposisi massa Li5FeO4. Nilai kapasitansi yang paling kecil terdapat pada fraksi massa karbon aktif kulit biji mete $60 \%$, sedangkan nilai kapasitansi yang paling besar terdapat pada fraksi massa karbon aktif kulit biji mete 20\%. Dari keempat fraksi massa, yang memiliki nilai kapasitansi yang paling besar dan setara dengan kapasitansi baterai lithium yang dijual dipasaran adalah pada fraksi massa karbon aktif kulit biji mete $20 \%$. Dalam penelitian ini hanya dilakukan satu kali sweep sehingga perlu dilakukan penelitian lanjutan dengan mengkompositkan karbon aktif kulit biji mete dan $\mathrm{Li}_{5} \mathrm{FeO}_{4}$ dengan menambah jumlah sweep pada karakterisasi Ciclyc Voltammetry untuk mengetahui performa bahan elektroda baterai lithium. Proses pembuatan bahan elektroda baterai lithium perlu dipadatkan terlebih dahulu sebelum diuji nilai kapasitansinya untuk mengurangi terbentuknya porositas pada sampel yang dapat mempengaruhi kecepatan transfer elektron saat reaksi redoks terjadi.

\section{DAFTAR PUSTAKA}

Adrianto, N., Mongkito, V. H. R., Fayanto, S., Anas, M., \& Eso, R. 2019. Characterization of activated charcoal from sugar palm bunches (Arengga pinnata (Wurmb) Merr) and the application as adsorbent lead $(\mathrm{Pb})$, copper $(\mathrm{Cu})$ and chrome $(\mathrm{Cr})$ in solution. In Journal of Physics: Conference Series (Vol. 1321, No. 2, p. 022002). IOP Publishing.

Ahmad, Undu, M. A. A., Ahmanas, S. R., Erniwati, \& Fayanto, S. 2019. Utilization of iron sand and activated carbon of cashew nut shell as a material basic of lithium battery. In AIP Conference Proceedings (Vol. 2169, No. 1, p. 060001). AIP Publishing LLC.

Alim, MI, Dina, M, Anita, DA, \& Diky, A. 2017. Uji Konduktivitas Termal Material Non Logam. Laporan Praktikum Laboratorium Fisika Material Institut Tknologi Sepuluh Nopember 
Allison-Bruce, SA, \& Abumere, OE. 2015. Microwave Assisted Hydrothermal Synthesis of $\mathrm{LiFePO}_{4} / \mathrm{C}$ Composite Cathode Material for Lithium-Ion Batteries. Department of Physics, University of Port Harcourt. Port Harcourt.

Amin, Y. 2019. Sintesis dan Karakterisasi Katoda Baterai Lithium Li5FeO4 Berbahan Baku Fe2O3 dari Pasir Besi dan Karbon Aktif Kulit Biji Mete. Skripsi. Universitas Halu Oleo.

Anas, M, Jahiding, M, Ratna, Hasanah, A, Kurniadi, D. 2014. Analisis Ultimate dan Sifat Struktur Arang Aktif dari Kulit Biji Mete: Pengaruh Temperatur Aktivasi. Prosiding Pertemuan Ilmiah XXVIII HFI Jateng \& DIY. Yogyakarta. ISSN: 0853-0823.

Chen, Y, Yulan, T, Yunzhong, Q, Zhifang, L, Huanhuan, H, Baojun, L, \& Huaqiang, C. 2019. Synthesis and Superior Cathode Performance of Sandwiched LiMn2O4@rGO Nanocomposites for Lithium-Ion Batteries. Materials Today Advance. Vol. 1.

Hanfeng, L, Wei, C, Yiwen, Y, Zhoucheng, W, \& Yong, Y. 2014. Hydrothermal synthesis, self-assembly and electrochemical performance. Ceramics International. hh.10283-10290.

Nursiti, Ersita, RW, Ayu, WS, Supriyono, \& Rama, O. 2018. Elektrosintesis Nanokomposit $\alpha-\mathrm{MnO}_{2} / \mathrm{C}$ dan Fabrikasinya untuk Aplikasi Superkapasitor. Jurnal Chemurgy. Vol. 2. No. 1
Panasonic, 'Lithium-ion Batteries : Models', dilihat tanggal 18 Juli 2020 < https://industrial.panasonic.com>

Rahardjo, RrAR, \& Supardi, ZAI. 2015. Sintesis dan Karakterisasi Material $\mathrm{Li}_{5} \mathrm{FeO}_{4}, \quad$ PVDF (PolyvinyLideneFluoride) dan Karbon Aktif dengan Aktivasi $\mathrm{HCl}$ sebagai Katoda Baterai LiIon. Jurnal Fisika. Vol. 04. No. 01. hh. 23 - 26.

Rajab. 2017. Sintesis Nanopartikel Manganese Ferrite $\left(\mathrm{MnFe}_{2} \mathrm{O}_{4}\right)$ Berbasis Pasir Besi Dan Mangan Alam Dengan Metode Reaksi Padatan. Skripsi. Universitas Halu Oleo

Rao, MC. 2013. Improving Electrochemical Performance of Lithium-Ion Batteries using $\mathrm{LiMn}_{2} \mathrm{O}_{4}$ Cathodes. $J$. Chem. Bio, Phy. Sci. Sec.C. Vol. 1

Subhan, A, Endang, S, Ramlan, Tiara, HU. 2015. Efek Penambahan Bahan Aditif MWCNT dan Acetylene Black (AB) pada Komposit $\mathrm{Li}_{4} \mathrm{Ti}_{5} \mathrm{O}_{12}$ sebagai Bahan Anoda untuk Baterai Li-Ion. Spektra: Jurnal Fisika dan Aplikasinya. Vol. 16, No. 2.

Syafindra, D, Esmar, B, \& Iwan, S. 2017. Rancang Bangun Sistem Potensiostat Menggunakan Arduino Uno. Prosiding SNIPS. ISBN: 978-602-61045-2-6

Taer, E, Zulkifli, Sugianto, R, Syech, R, \& Taslim. 2015. Analaisa Siklis Voltametri Superkapasitor Menggunakan Elektroda Karbon Aktif dari Kayu Karet berdasarkan Variasi Aktivator KOH. Prosiding Seminar Nasional Fisika. Vol. 4 